\title{
THE EFFECTS OF A SODIUM AND A CALCIUM CHANNEL BLOCKER ON LETHALITY OF MICE INJECTED WITH THE YELLOW SCORPION (Leiurus quinquestriatus) VENOM
}

\author{
AL-SHANAWANI A. R. (1), FATANI A. J. (1), EL-SAYED F. H. (1)
}

(1) Department of Pharmacology, College of Pharmacy, King Saud University, Riyadh, Saudi Arabia.

\begin{abstract}
Scorpion venom toxins generally produce similar effects by mainly acting on sodium channels, and to a lesser extent, on potassium, calcium, and chloride channels. This leads to increased release of neurotransmitters and mediators, resulting in a cascade of pathological events, involving the central nervous system, the autonomic nervous system, the cardiovascular and the respiratory system, eventually leading to death. The objective of this paper was to discover whether a sodium channel blocker, lidocaine, or a calcium channel blocker, verapamil, would prolong the survival of mice injected with the venom from the common yellow scorpion Leiurus quinquestriatus quinquestriatus (LQQ). For this purpose, mice were divided into 2 groups, each injected with a different venom dose (250 or $300 \mu \mathrm{g} \cdot \mathrm{kg}^{-1}$, s.c.). Subgroups $(n=10)$ from each group were given venom alone; different doses of lidocaine $\left(4,10,15\right.$, or $\left.20 \mathrm{mg} \cdot \mathrm{kg}^{-1}\right)$; or several doses of verapamil $\left(0.01,0.03,0.1,0.3\right.$, or $\left.1 \mathrm{mg}^{\mathrm{kg}}{ }^{-1}\right)$. All doses of lidocaine and verapamil were intravenously administered 3 minutes before, 1,5 , and 15 minutes after venom injection. Percent surviving after 24 hours was recorded in addition to the time of death. In general, lidocaine significantly prolonged survival at the dose of $10 \mathrm{mg} \cdot \mathrm{kg}^{-1}$ $\left(P<0.05\right.$ and $P<0.01$, versus low and high dose of venom, respectively) or $15 \mathrm{mg} . \mathrm{kg}^{-1}$ $(P<0.01$ and $P<0.001$, versus low and high dose of venom, respectively; Covariance Wilcoxon survival statistics), especially when injected before the venom or in the early stages of envenomation. On the other hand, in all doses administered, verapamil was either toxic or showed non-significant results. Lidocaine, the sodium channel blocker, appears to play an important role in the protection from lethality of mice injected with $L Q Q$ venom, and significantly prolonged the survival time of mice whether injected before or in the early stages of envenomation.
\end{abstract}

KEY WORDS: Leiurus quinquestriatus quinquestriatus, scorpion venom, neurotoxins, $\mathrm{Na}^{+}$channels, $\mathrm{Ca}^{2+}$ channels, lidocaine, verapamil, mice, lethality.

\section{CORRESPONDENCE TO:}

A. R. M. AL-SHANAWANI, Department of Pharmacology, College of Pharmacy, King Saud University, P.O. Box: 616, Riyadh, 11421, Kingdom of Saudi Arabia. Phone: 00966 505253907. Fax. 009661 4115376. Email: ash77 00@hotmail.com. 
A. R. Al-Shanawani et al. THE EFFECTS OF A SODIUM AND A CALCIUM CHANNEL BLOCKER ON LETHALITY OF MICE INJECTED WITH THE YELLOW SCORPION (Leiurus quinquestriatus) VENOM. J. Venom. Anim. Toxins incl. Trop. Dis., 2005, 11, 2, p. 176

\section{INTRODUCTION}

The kingdom of Saudi Arabia is a vast country located between the temperate and tropical geographical regions. As with similar areas, it is known to harbor many species of the most venomous scorpions that can present medical problems and life hazards, especially for children (10). The toxins in these scorpions have been divided into two types, $\alpha$ and $\beta$, based on their pharmacological effects on $\mathrm{Na}^{+}$channels (36). The $\alpha$ toxins, such as those in Leiurus quinquestriatus quinquestriatus, an Old World scorpion very common throughout the Middle East, bind to site 3 of $^{\mathrm{Na}^{+}}$channels, slowing or blocking the inactivation mechanism of these channels $(36,44)$. This would lead to prolonged action potential, sustained depolarization, and uncontrolled release of several neurotransmitters such as acetylcholine (18), noradrenaline (32) and adrenaline (29), in addition to several pharmacologically active endogenous substances such as histamine (7), cytokines (33), bradykinins (31) and prostaglandins (15). This usually results in detrimental venom-evoked pathological changes in several systems including the cardiovascular, respiratory, nervous, muscular, gastro-intestinal, and immunological system, and ultimately death $(23,26)$. Although several researchers have utilized scorpion $\alpha$ toxins in studying the structure and function of $\mathrm{Na}^{+}$channels $(4,19)$, few have advocated the utilization of $\mathrm{Na}^{+}$ channel blockers to treat victims, by preventing the first step in the whole cascade that occurs following scorpion envenomation (12, 41, 43). Freire-Maia and Campos (13) employed lidocaine solely to relieve pain at sting site following scorpion envenomation. However, Barzilay et al. (1) utilized lidocaine to treat $L Q Q$ venomevoked arrhythmias. In addition, Vital et al. (41) showed that lidocaine was useful in the treatment of arrhythmia and hypertension following envenomation by Androctonus australis and LQQ. Moreover, Fatani et al. (12) showed the effectiveness of pretreatment with lidocaine in protecting rabbits from venom-induced cardiovascular changes and prolonging survival. To the best of our knowledge, no or little work has been done showing whether early administration of a $\mathrm{Na}^{+}$channel blocker after envenomation would avoid all the subsequent venom-elicited sequelae and thus enhance survival. This would change therapy towards alleviation of the original pathological cause, rather than symptomatic treatment of the aftermath.

On another work, several authors have reported a role for altered $\mathrm{Ca}^{2+}$ influx in $L Q Q$ scorpion venom eliciting pathological changes in different systems such as skeletal 
A. R. Al-Shanawani et al. THE EFFECTS OF A SODIUM AND A CALCIUM CHANNEL BLOCKER ON LETHALITY OF MICE INJECTED WITH THE YELLOW SCORPION (Leiurus quinquestriatus) VENOM. J. Venom. Anim. Toxins incl. Trop. Dis., 2005, 11, 2, p. 177

(45) and cardiac muscles $(9,20)$. Additionally, several scorpion venoms have been known to affect $\mathrm{Ca}^{2+}$ release from sarcoplasmic reticulum in skeletal and cardiac muscles by binding to ryanodine receptors that regulate intracellular free $\mathrm{Ca}^{2+}$ concentration, and whose elevation triggers a cascade of events culminating in muscle contraction $(11,39)$. It is also known that in addition to the activation of sodium and potassium channels, $\mathrm{Ca}^{2+}$ influx is essential for neurotransmitter release in several systems, and is governed by a number of high-voltage-operated $\mathrm{Ca}^{2+}$ channels (35). Since scorpion venom acts by prolonging the action potential, leading to sustained depolarization, and uncontrolled neurotransmitter release, it seems logical that blocking $\mathrm{Ca}^{2+}$ channels may prevent the exaggerated venom-evoked release of transmitters and mediators, thus positively altering the consequent sequelae $(28,38)$. In addition, Gueron and Sofer (21) and Bawaskar and Bawaskar (2) showed that nifedipine and/or verapamil, both calcium channel blockers, when utilized as vasodilators in treating venom-elicited hypertension, appeared to be effective. It would be interesting to discover whether the efficacy of these drugs could be attributed not only to their vasodilator effects but also to their channel blocking capabilities. If it is proven to be correct, these blockers may be administered in the earlier stages of envenomation and might also help in preventing the venom-evoked exaggerated neurotransmitters release and the subsequent pathological changes, thus prolonging survival.

\section{Aim of the Work}

Although there are many studies on the prevention of the detrimental toxicities that occur after scorpion envenomation, a lot of work is still necessary. It is a dilemma to decide on modules of treatment that would cover all damages, which usually depend on symptomatic treatment rather than the original cause of the pathological sequelae. Thus the aim of this study is to discover whether a sodium channel blocker, such as lidocaine, or a calcium channel blocker, such as verapamil, given either before or at different times after scorpion envenomation, would halt or reduce the venom-elicited subsequent cascade of events, and ultimately extend survival. This is the first in a series of both in vivo and in vitro experiments that will study the protective effects of lidocaine on different systems. 
A. R. Al-Shanawani et al. THE EFFECTS OF A SODIUM AND A CALCIUM CHANNEL BLOCKER ON LETHALITY OF MICE INJECTED WITH THE YELLOW SCORPION (Leiurus quinquestriatus) VENOM. J. Venom. Anim. Toxins incl. Trop. Dis., 2005, 11, 2, p. 178

\section{MATERIALS AND METHODS}

Swiss Albino mice $(22.5 \pm 0.01 \mathrm{~g})$ were obtained from the Animal Care Center, College of Pharmacy, King Saud University. They were kept at the Animal Care Unit at ambient temperature with food and water ad libitum. The experiments were carried out according to the institution's guide for the care and use of laboratory animals. Leiurus quinquestriatus quinquestriatus venom was obtained from the Antivenom Center of the King Fahad National Guard Hospital; lidocaine from Astra (Sweden); and verapamil from Sabex INC. (Canada).

Groups of 10 mice were injected subcutaneously with one of the following doses of LQQ scorpion venom: $100,150,200,250,300,350,400,450$, and $500 \mu \mathrm{g} \cdot \mathrm{kg}^{-1}$. The experiment was then repeated with the same doses of venom injected intravenously via the mouse tail vein. The number of dead animals in every group was recorded after 24 hours. The lethal dose that killed $50 \%$ of the animals $\left(L D_{50}\right)$ plus the minimal lethal dose (MLD) were then calculated for both the subcutaneous and intravenous routes, according to the Miller and Tainter method (34).

In another set of experiments mice were randomized into two main groups, each injected with a different dose of venom (250 or $300 \mu$ g. $\mathrm{kg}^{-1}$, s.c.). Subgroups $(n=10)$ from each group were given venom alone; different doses of lidocaine $(4,10,15$, or $\left.20 \mathrm{mg} . \mathrm{kg}^{-1}\right)$; or several doses of verapamil $\left(0.01,0.03,0.1,0.3\right.$, or $\left.1 \mathrm{mg} . \mathrm{kg}^{-1}\right)$. All doses of lidocaine and verapamil were intravenously administered 3 minutes before, and 1, 5, and 15 minutes after venom injection. Proper positive and negative controls utilizing $L Q Q$, lidocaine, verapamil and $0.9 \% \mathrm{NaCl}$ were simultaneously performed. Time of death plus percent surviving after 24 hours were recorded. Covariance Wilcoxon survival statistics and survival distribution curves were determined utilizing SAS program, with the aid of the Biomedical Statistics Department at the King Faisal Specialist Hospital Research Center.

\section{RESULTS}

\section{Effect of intravenous injection of $0.9 \% \mathrm{NaCl}$ on mice}

For control, 10 male mice $(22.5 \pm 0.08 \mathrm{~g})$ were injected with $0.9 \% \mathrm{NaCl}(0.2 \mathrm{ml} / 20 \mathrm{~g}$ mouse, i.v.). All the animals were alive at the end of the 24-hour time limit of the experiment with no outward signs of toxicity. 
A. R. Al-Shanawani et al. THE EFFECTS OF A SODIUM AND A CALCIUM CHANNEL BLOCKER ON LETHALITY OF MICE INJECTED WITH THE YELLOW SCORPION (Leiurus quinquestriatus) VENOM. J. Venom. Anim. Toxins incl. Trop. Dis., 2005, 11, 2, p. 179

Effect of intravenous and subcutaneous injection of $L Q Q$ venom on the survival of mice

Gradually increasing doses of $L Q Q$ venom $\left(100-500 \mu \mathrm{g} \cdot \mathrm{kg}^{-1}\right.$, either i.v. or s.c.) were injected in male mice. The $\mathrm{LD}_{50}$ was calculated to be 220 and $240 \mu \mathrm{g} \cdot \mathrm{kg}^{-1}$ for the intravenous and subcutaneous routes, respectively; while the MLD, 330 and 350 $\mu \mathrm{g} . \mathrm{kg}^{-1}$, respectively (Tables 1 and 2 ). All the animals injected with venom doses higher than $200 \mu \mathrm{g} \cdot \mathrm{kg}^{-1}$ developed the following symptoms in varying degrees: agitation, aggressive behavior, increased respiration, hypersalivation, lacrimation, micturition, defecation, shivering, periodic spastic contractions, gasping, convulsions, and, in fatal cases, cardiac and respiratory arrest.

In all subsequent experiments, animals were injected subcutaneously to simulate the natural route of envenomation. For this purpose we utilized 2 venom doses (250 and $300 \mu \mathrm{g} \cdot \mathrm{kg}^{-1}$ ); the first was expected to kill more than $50 \%$ of the animals and the second less than $100 \%$, without any therapeutic interventions. These experiments showed that the percent survival averaged $28 \% \pm 1.64$ and $5 \% \pm 1.89$ for 250 and 300 $\mu \mathrm{g} . \mathrm{kg}^{-1}$ of $L Q Q$ venom, respectively. Additionally, the average survival time was $36 \pm 1.23 \mathrm{~min}$ and $30 \pm 2.19 \mathrm{~min}$ for the low and high dose of venom, respectively.

\section{Effect of intravenous injection of lidocaine and verapamil on mice}

For control, male mice were divided into two groups; the first was injected with

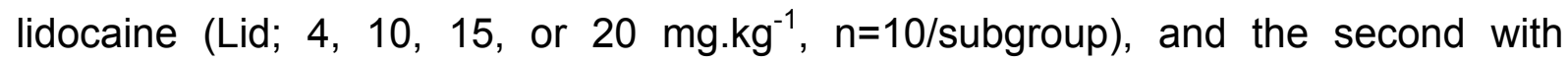
verapamil $\left(\mathrm{V}, 0.01,0.03,0.1\right.$, or $\left.0.3 \mathrm{mg} . \mathrm{kg}^{-1}\right)$. In both cases, the doses used were known to affect calcium and sodium channels $(17,30)$. All animals were alive at the end of the 24-hour time limit of the experiment with no outward signs of toxicity.

\section{Effect of administration of lidocaine on the survival of mice injected with $L Q Q$ venom}

Based on the survival time of envenomed mice, it was decided that, in addition to pretreating the animals with either lidocaine or verapamil, they would be injected immediately after (1 $\mathrm{min})$, early $(5 \mathrm{~min})$ and at a later stage (15 $\mathrm{min}$ ) following envenomation in order to assess the best time for intervention.

Lidocaine, in doses ranging from 4 to $20 \mathrm{mg} \cdot \mathrm{kg}^{-1}$, was intravenously administered 3 min before, and 1,5 , and 15 min after injecting $L Q Q$ venom (250 or $300 \mu \mathrm{g} \cdot \mathrm{kg}^{-1}$ ) 
A. R. Al-Shanawani et al. THE EFFECTS OF A SODIUM AND A CALCIUM CHANNEL BLOCKER ON LETHALITY OF MICE INJECTED WITH THE YELLOW SCORPION (Leiurus quinquestriatus) VENOM. J. Venom. Anim. Toxins incl. Trop. Dis., 2005, 11, 2, p. 180

(Tables 3 and 4); and the survival distribution function curves were drawn. In general, with both doses of venom, lidocaine significantly prolonged survival when injected at the dose of $10 \mathrm{mg} \cdot \mathrm{kg}^{-1} \quad(\mathrm{P}<0.05$ and $\mathrm{P}<0.01$, vs low and high dose of venom, respectively, Figures $1 \mathrm{l}$ and $2 \mathrm{l}$ ) or $15 \mathrm{mg}^{\mathrm{kg}} \mathrm{k}^{-1}(\mathrm{P}<0.05$ and $\mathrm{P}<0.001$, vs low and high dose of venom, respectively; Figures $1 \mathrm{II}$ and 2II; Covariance Wilcoxon survival statistics).

Analysis of individual experiments showed that injection of $4 \mathrm{mg} \cdot \mathrm{kg}^{-1}$ Lid was incapable of altering the outcome whether injected before or after both doses of venom. When animals received Lid (10-20 mg. $\left.\mathrm{kg}^{-1}\right) 3 \mathrm{~min}$ before the low dose of venom $\left(250 \mu \mathrm{g} \cdot \mathrm{kg}^{-1}\right)$, the survival time was significantly increased with the dose of 10 mg.kg ${ }^{-1}$ ( $P<0.05$ vs venom). Moreover, both percent survival and survival time were significantly elevated with the dose of $15 \mathrm{mg}^{\mathrm{kg}} \mathrm{k}^{-1}$ ( $\mathrm{P}<0.01 \mathrm{vs}$ venom). When injected $1 \mathrm{~min}$ after the venom, Lid (15 and $20 \mathrm{mg} \cdot \mathrm{kg}^{-1}$ ) significantly elevated both percent survival and survival time $(\mathrm{P}<0.05$ vs venom). Furthermore, Lid significantly increased survival time $\left(P<0.01\right.$, vs venom), in the dose of $15 \mathrm{mg} . \mathrm{kg}^{-1}$, and percent survival $\left(P<0.01\right.$, vs venom), in the dose of $20 \mathrm{mg} \cdot \mathrm{kg}^{-1}$, when injected $5 \mathrm{~min}$ after $L Q Q$ venom. Surprisingly, when Lid was injected 15 min after $L Q Q$ venom, only animals treated with $10 \mathrm{mg} \cdot \mathrm{kg}^{-1}$ presented a significant prolongation in both percent survival and survival time ( $P<0.05$ vs venom; Table 3$)$.

A similar pattern was observed with the high dose of venom $\left(300 \mu \mathrm{g} . \mathrm{kg}^{-1}\right)$ when Lid was injected 3 min before, significantly increasing the percent survival $(P<0.01$ for 15 mg.kg ${ }^{-1}$ ) and survival time ( $P<0.05$ for 10 and 20 mg. $\mathrm{kg}^{-1} ; \mathrm{P}<0.001$ for $15 \mathrm{mg} \cdot \mathrm{kg}^{-1}$ ) versus venom alone. Unlike the results obtained with the lower dose of venom, when animals were treated with Lid $1 \mathrm{~min}$ after the venom, a significant protection was provided only by $10 \mathrm{mg} \cdot \mathrm{kg}^{-1}$ (survival time, $\mathrm{P}<0.05$ ) vs venom-injected group. Also, when Lid was injected $5 \mathrm{~min}$ after $L Q Q$ venom, there was a significant difference in survival time $\left(P<0.05\right.$ and $P<0.001$, for Lid 10 and $15 \mathrm{mg} \cdot \mathrm{kg}^{-1}$, respectively). Furthermore, when Lid was injected $15 \mathrm{~min}$ after the venom, percent survival of animals given 10 and $15 \mathrm{mg}^{\mathrm{kg}}{ }^{-1}$ was significantly higher than the corresponding venom-treated animals $(P<0.05)$. In addition, survival time was also significantly elevated with $15 \mathrm{mg} \cdot \mathrm{kg}^{-1} \mathrm{Lid}(\mathrm{P}<0.05$, vs venom alone; Table 4). 
A. R. Al-Shanawani et al. THE EFFECTS OF A SODIUM AND A CALCIUM CHANNEL BLOCKER ON LETHALITY OF MICE INJECTED WITH THE YELLOW SCORPION (Leiurus quinquestriatus) VENOM. J. Venom. Anim. Toxins incl. Trop. Dis., 2005, 11, 2, p. 181

Effect of administration of verapamil on the survival of mice injected with $L Q Q$ venom

To compare the efficacy of the sodium channel blocker (lidocaine) with that of verapamil (a calcium channel blocker) in protecting $L Q Q$-envenomed mice, animals were injected with several doses of $\mathrm{V}\left(0.01,0.03,0.1\right.$, or $\left.0.3 \mathrm{mg} . \mathrm{kg}^{-1}\right) 3 \mathrm{~min}$ before and 1,5 , and $15 \mathrm{~min}$ after 250 or $300 \mu \mathrm{g} \cdot \mathrm{kg}^{-1} L Q Q$ venom (Tables 5 and 6 plus Figures 3I, 3II, 4I, and 4II). Unlike the results obtained with Lid, regardless of the $\mathrm{V}$ dose utilized in these experiments or its time of injection, no significant difference was observed between envenomed animals treated with verapamil or those given venom alone. On the contrary, $\mathrm{V}$ significantly shortened survival time of mice when injected at the dose of $0.03 \mathrm{mg} \cdot \mathrm{kg}^{-1}$, either 5 or $15 \mathrm{~min}$ after $300 \mu \mathrm{g} \cdot \mathrm{kg}^{-1} L Q Q$ venom $(\mathrm{P}<0.05$, vs venom alone).

Table 1: Effect of different doses of $L Q Q$ venom, injected subcutaneously, on mice lethality.

\begin{tabular}{cccccc}
\hline Group No. $^{\mathbf{a}}$ & $\begin{array}{c}\text { LQQ Venom } \\
\text { Dose } \\
\left(\mu \mathrm{g} \cdot \mathrm{kg}^{-1}\right)\end{array}$ & $\begin{array}{c}\text { Dead } \\
\text { Animals } \\
(\text { No. })\end{array}$ & $\begin{array}{c}\text { Surviving } \\
\text { Animals } \\
(\text { No. })\end{array}$ & $\begin{array}{c}\text { Dead } \\
\text { Animals } \\
(\%)\end{array}$ & $\begin{array}{c}\text { Correction } \\
(\%)\end{array}$ \\
\hline II & 500 & 10 & 0 & 100 & --- \\
III & 450 & 10 & 0 & 100 & --- \\
IV & 400 & 10 & 0 & 100 & --- \\
V & 350 & 10 & 0 & 100 & 99.75 \\
VI & 300 & 8 & 2 & 80 & 80 \\
VII & 250 & 6 & 4 & 60 & 60 \\
VIII & 150 & 3 & 7 & 30 & 30 \\
IX & 100 & 1 & 9 & 10 & 10 \\
\hline
\end{tabular}

a Each group containing 10 male mice $(22.5 \pm 0.08 \mathrm{~g})$

b According to Miller and Tainter method (1944)

- $L Q Q$ venom $L_{50}=240 \mu \mathrm{g} \cdot \mathrm{kg}^{-1}$; minimum lethal dose $(\mathrm{MLD})=350 \mu \mathrm{g} \cdot \mathrm{kg}^{-1}$ 
A. R. Al-Shanawani et al. THE EFFECTS OF A SODIUM AND A CALCIUM CHANNEL BLOCKER ON LETHALITY OF MICE INJECTED WITH THE YELLOW SCORPION (Leiurus quinquestriatus) VENOM. J. Venom. Anim. Toxins incl. Trop. Dis., 2005, 11, 2, p. 182

Table 2: Effect of different doses of $L Q Q$ venom, injected intravenously, on mice lethality.

\begin{tabular}{cccccc}
\hline Group No. $^{\text {a }}$ & $\begin{array}{c}\text { LQQ Venom } \\
\text { Dose } \\
\left(\mu \mathrm{g} \cdot \mathrm{kg}^{-1}\right)\end{array}$ & $\begin{array}{c}\text { Dead } \\
\text { Animals } \\
(\text { No. })\end{array}$ & $\begin{array}{c}\text { Surviving } \\
\text { Animals } \\
(\text { No. })\end{array}$ & $\begin{array}{c}\text { Dead } \\
\text { Animals } \\
(\%)\end{array}$ & $\begin{array}{c}\text { Correction } \\
(\%)\end{array}$ \\
\hline I & 500 & 10 & 0 & 100 & -- \\
II & 450 & 10 & 0 & 100 & -- \\
III & 400 & 10 & 0 & 100 & --- \\
IV & 350 & 10 & 0 & 100 & 99.75 \\
V & 300 & 9 & 1 & 90 & 90 \\
VI & 250 & 8 & 2 & 80 & 80 \\
VII & 200 & 4 & 6 & 40 & 40 \\
VIII & 150 & 2 & 8 & 20 & 20 \\
IX & 100 & 0 & 10 & 0 & 2.5 \\
\hline
\end{tabular}

a Each group containing 10 male mice $(22.2 \pm 0.12 \mathrm{~g})$

${ }^{b}$ According to Miller and Tainter method (1944)

$-L Q Q$ venom $L D_{50}=220 \mu \mathrm{g} \cdot \mathrm{kg}^{-1} ;$ minimum lethal dose $(M L D)=330 \mu \mathrm{g} \cdot \mathrm{kg}^{-1}$ 
A. R. Al-Shanawani et al. THE EFFECTS OF A SODIUM AND A CALCIUM CHANNEL BLOCKER ON LETHALITY OF MICE INJECTED WITH THE YELLOW SCORPION (Leiurus quinquestriatus) VENOM. J. Venom. Anim. Toxins incl. Trop. Dis., 2005, 11, 2, p. 183

Table 3: Percent survival and average time of death of mice intravenously injected with lidocaine (Lid) at different times before and after $L Q Q$ venom $\left(250 \mu \mathrm{g} . \mathrm{kg}^{-1}\right.$, s.c.).

\begin{tabular}{|c|c|c|c|c|c|c|c|c|}
\hline $\begin{array}{l}\text { Lid } \\
\text { Dose }\end{array}$ & \multicolumn{2}{|c|}{$4 \mathrm{mg} \cdot \mathrm{kg}^{-1}$} & \multicolumn{2}{|c|}{$10 \mathrm{mg} \cdot \mathrm{kg}^{-1}$} & \multicolumn{2}{|c|}{$15 \mathrm{mg} \cdot \mathrm{kg}^{-1}$} & \multicolumn{2}{|c|}{$20 \mathrm{mg} \cdot \mathrm{kg}^{-1}$} \\
\hline$\underset{\mathbf{a}}{\text { Groups }}$ & $\begin{array}{c}\text { Survival } \\
(\%)\end{array}$ & $\begin{array}{c}\text { Average } \\
\text { Time of } \\
\text { Death } \\
\text { (min) }\end{array}$ & $\begin{array}{c}\text { Survival } \\
(\%)\end{array}$ & $\begin{array}{c}\text { Average } \\
\text { Time of } \\
\text { Death } \\
\text { (min) }\end{array}$ & $\begin{array}{c}\text { Survival } \\
(\%)\end{array}$ & $\begin{array}{l}\text { Average } \\
\text { Time of } \\
\text { Death } \\
\text { (min) }\end{array}$ & $\begin{array}{c}\text { Survival } \\
(\%)\end{array}$ & $\begin{array}{c}\text { Average } \\
\text { Time of } \\
\text { Death } \\
\text { (min) }\end{array}$ \\
\hline (i) & 30 & $37 \pm 5.1$ & 30 & $38 \pm 3.3$ & 30 & $38 \pm 2.5$ & 20 & $33 \pm 3.2$ \\
\hline (ii) & 60 & $50 \pm 6.5$ & 60 & $63 \pm 5.6^{*}$ & $70^{* *}$ & $87 \pm 0.47^{* \star}$ & 40 & $59 \pm 7.9$ \\
\hline (iii) & $20^{\#}$ & $50 \pm 6.2$ & $20^{\#}$ & $52 \pm 9.9$ & 50 * & $75 \pm 11.5^{*}$ & 70 * & $100 \pm 8.7^{*}$ \\
\hline (iv) & $20^{\#}$ & $51 \pm 3.5$ & 60 & $56 \pm 3.2$ & 40 & $104 \pm 12.3^{* *}$ & $90^{* *}$ & 27 \\
\hline (v) & $20^{\#}$ & $50 \pm 7.7$ & $70^{*} \Delta$ & $92 \pm 4.1^{*} \boldsymbol{\Delta}$ & 30 & $33 \pm 5.6$ & 44 & $33 \pm 5.4$ \\
\hline
\end{tabular}

(i) $L Q Q$ venom alone

(ii) $L Q Q$ venom 3 min after Lid

(iii) $L Q Q$ venom $1 \mathrm{~min}$ before Lid

(iv) $L Q Q$ venom $5 \mathrm{~min}$ before Lid

(v) $L Q Q$ venom $15 \mathrm{~min}$ before Lid

${ }^{\mathrm{a}} \mathrm{n}=10$ male mice/group; weight $=21.8 \pm 0.14 \mathrm{~g}$

* values significantly different from (i) ( $\left.{ }^{*} \mathrm{P}<0.05 ;{ }^{* *} \mathrm{P}<0.01\right)$

\# values significantly different from (ii) ( $\left.{ }^{\#} \mathrm{P}<0.05\right)$

$\triangle$ values significantly different from (iii) $\left({ }^{\mathbf{P}} \mathrm{P}<0.01\right)$; Wilcoxon survival statistics

- All animals injected with either $0.9 \% \mathrm{NaCl}$ or Lid (controls) were alive and well after $24 \mathrm{~h}$. 
A. R. Al-Shanawani et al. THE EFFECTS OF A SODIUM AND A CALCIUM CHANNEL BLOCKER ON LETHALITY OF MICE INJECTED WITH THE YELLOW SCORPION (Leiurus quinquestriatus) VENOM. J. Venom. Anim. Toxins incl. Trop. Dis., 2005, 11, 2, p. 184

Table 4: Percent survival and average time of death of mice intravenously injected with lidocaine (Lid) at different times before and after $L Q Q$ venom $\left(300 \mu \mathrm{g} \cdot \mathrm{kg}^{-1}\right.$, s.c.).

\begin{tabular}{ccccccccc}
\hline $\begin{array}{c}\text { Lid } \\
\text { Dose }\end{array}$ & \multicolumn{2}{c}{$4 \mathrm{mg}_{\mathrm{kg}}{ }^{-1}$} & \multicolumn{2}{c}{$10 \mathrm{mg} \cdot \mathrm{kg}^{-1}$} & \multicolumn{2}{c}{$15 \mathrm{mg}^{-\mathrm{kg}^{-1}}$} & $20 \mathrm{mg}^{-\mathrm{kg}^{-1}}$ \\
\hline $\begin{array}{c}\text { Groups } \\
\text { a }\end{array}$ & $\begin{array}{c}\text { Survival } \\
(\%)\end{array}$ & $\begin{array}{c}\text { Average } \\
\text { time of } \\
\text { Death } \\
(\mathrm{min})\end{array}$ & $\begin{array}{c}\text { Survival } \\
(\%)\end{array}$ & $\begin{array}{c}\text { Average } \\
\text { time of } \\
\text { Death } \\
(\mathrm{min})\end{array}$ & $\begin{array}{c}\text { Survival } \\
(\%)\end{array}$ & $\begin{array}{c}\text { Average } \\
\text { time of } \\
\text { Death } \\
(\mathrm{min})\end{array}$ & $\begin{array}{c}\text { Survival } \\
(\%)\end{array}$ & $\begin{array}{c}\text { Average } \\
\text { time of } \\
\text { Death } \\
(\mathrm{min})\end{array}$ \\
\hline (i) & 0 & $27 \pm 2.5$ & 0 & $27 \pm 2.5$ & 0 & $22 \pm 1.9$ & 10 & $32 \pm 2.03$ \\
(ii) & 0 & $31 \pm 3.7$ & 20 & $41 \pm 3.9^{*}$ & $50^{* *}$ & $67 \pm 4.1^{* * *}$ & 20 & $89 \pm 9.5^{*}$ \\
(iii) & 0 & $27 \pm 1.7$ & 0 & $42 \pm 2.2^{*}$ & $20^{\#}$ & $32 \pm 8.7^{\#}$ & 30 & $65 \pm 17.2$ \\
(iv) & 0 & $24 \pm 1.4$ & 10 & $50 \pm 6.1$ & 0 & $78 \pm 10.4^{* * *}$ & 20 & $49 \pm 8.3$ \\
(v) & 0 & $30 \pm 2.1$ & $30^{*}$ & $35 \pm 7.4$ & $30^{*}$ & $59 \pm 14.1^{*}$ & 60 & $26 \pm 2.4$ \\
\hline
\end{tabular}

(i) $L Q Q$ venom alone

(ii) $L Q Q$ venom 3 min after Lid

(iii) $L Q Q$ venom $1 \mathrm{~min}$ before Lid

(iv) $L Q Q$ venom $5 \mathrm{~min}$ before Lid

(v) $L Q Q$ venom $15 \mathrm{~min}$ before Lid

${ }^{\mathrm{a}} \mathrm{n}=10$ male mice/group; weight $=20.7 \pm 0.2 \mathrm{~g}$

${ }^{*}$ values significantly different from (i) $\left({ }^{*} \mathrm{P}<0.05 ;{ }^{* *} \mathrm{P}<0.01\right.$; $\left.{ }^{* *} \mathrm{P}<0.001\right)$

\# values significantly different from (ii) $\left({ }^{\#} \mathrm{P}<0.05\right)$

$\Delta$ values significantly different from (iii) $\left({ }^{\mathbf{P}} \mathrm{P}<0.05\right)$; Wilcoxon survival statistics

- All animals injected with either $0.9 \% \mathrm{NaCl}$ or Lid (controls) were alive and well after $24 \mathrm{~h}$. 
A. R. Al-Shanawani et al. THE EFFECTS OF A SODIUM AND A CALCIUM CHANNEL BLOCKER ON LETHALITY OF MICE INJECTED WITH THE YELLOW SCORPION (Leiurus quinquestriatus) VENOM. J. Venom. Anim. Toxins incl. Trop. Dis., 2005, 11, 2, p. 185

Table 5: Percent survival and average time of death of mice intravenously injected with verapamil $(V)$ at different times before and after $L Q Q$ venom $\left(250 \mu \mathrm{g} \cdot \mathrm{kg}^{-1}\right.$, s.c. $)$.

\begin{tabular}{|c|c|c|c|c|c|c|c|c|}
\hline V Doses & \multicolumn{2}{|c|}{$0.01 \mathrm{mg} \cdot \mathrm{kg}^{-1}$} & \multicolumn{2}{|c|}{$0.03 \mathrm{mg} \cdot \mathrm{kg}^{-1}$} & \multicolumn{2}{|c|}{$0.1 \mathrm{mg} \cdot \mathrm{kg}^{-1}$} & \multicolumn{2}{|c|}{$0.3 \mathrm{mg} \cdot \mathrm{kg}^{-1}$} \\
\hline$\underset{\mathrm{a}}{\text { Groups }}$ & $\begin{array}{c}\text { Survival } \\
(\%)\end{array}$ & $\begin{array}{l}\text { Average } \\
\text { time of } \\
\text { Death } \\
\text { (min) }\end{array}$ & $\begin{array}{c}\text { Survival } \\
(\%)\end{array}$ & $\begin{array}{l}\text { Average } \\
\text { time of } \\
\text { Death } \\
\text { (min) }\end{array}$ & $\begin{array}{c}\text { Survival } \\
(\%)\end{array}$ & $\begin{array}{c}\text { Average } \\
\text { time of } \\
\text { Death } \\
\text { (min) }\end{array}$ & $\begin{array}{c}\text { Survival } \\
(\%)\end{array}$ & $\begin{array}{c}\text { Average } \\
\text { time of } \\
\text { Death } \\
(\mathrm{min})\end{array}$ \\
\hline (i) & 30 & $35 \pm 2.6$ & 20 & $34 \pm 2.2$ & 30 & $42 \pm 3.3$ & 30 & $31 \pm 0.9$ \\
\hline (ii) & 20 & $34 \pm 1.6$ & 10 & $38 \pm 2.7$ & 40 & $37 \pm 4.3$ & 30 & $24 \pm 1.1$ \\
\hline (ii) & 20 & $48 \pm 9.9$ & 10 & $46 \pm 8.7$ & 50 & $69 \pm 10.9$ & 30 & $26 \pm 1.3$ \\
\hline (iv) & 20 & $42 \pm 7.1$ & 20 & $44 \pm 8.1$ & 40 & $39 \pm 4.1$ & 30 & $22 \pm 1.8$ \\
\hline (v) & 0 & $33 \pm 1.6$ & 0 & $42 \pm 4.9$ & 30 & $34 \pm 2.9$ & 40 & $27 \pm 2.2$ \\
\hline
\end{tabular}

(i) $L Q Q$ venom alone

(ii) $L Q Q$ venom 3 min after $V$

(iii) $L Q Q$ venom 5 min before $V$

(iv) $L Q Q$ venom $15 \mathrm{~min}$ before $\mathrm{V}$

${ }^{\mathrm{a}} \mathrm{n}=10$ male mice/group; weight $=19.9 \pm 0.08 \mathrm{~g}$

- All animals injected with either $0.9 \% \mathrm{NaCl}$ or $\mathrm{V}$ (controls) were alive and well after $24 \mathrm{~h}$ 
A. R. Al-Shanawani et al. THE EFFECTS OF A SODIUM AND A CALCIUM CHANNEL BLOCKER ON LETHALITY OF MICE INJECTED WITH THE YELLOW SCORPION (Leiurus quinquestriatus) VENOM. J. Venom. Anim. Toxins incl. Trop. Dis., 2005, 11, 2, p. 186

Table 6: Percent survival and average time of death of mice intravenously injected with verapamil $(\mathrm{V})$ at different times before and after $L Q Q$ venom $\left(300 \mu \mathrm{g} \cdot \mathrm{kg}^{-1}\right.$, s.c).

\begin{tabular}{ccccccccc} 
V Dose & \multicolumn{2}{c}{$0.01 \mathrm{mg}_{\mathrm{kg}}{ }^{-1}$} & \multicolumn{2}{c}{$0.03 \mathrm{mg} \cdot \mathrm{kg}^{-1}$} & \multicolumn{2}{c}{$0.1 \mathrm{mg}^{\mathrm{kg}}{ }^{-1}$} & \multicolumn{2}{c}{$0.3 \mathrm{mg}^{\mathrm{kg}}{ }^{-1}$} \\
\hline Groups $^{\text {a }}$ & $\begin{array}{c}\text { Survival } \\
(\%)\end{array}$ & $\begin{array}{c}\text { Average } \\
\text { time of } \\
\text { Death } \\
(\mathrm{min})\end{array}$ & $\begin{array}{c}\text { Survival } \\
(\%)\end{array}$ & $\begin{array}{c}\text { Average } \\
\text { time of } \\
\text { Death } \\
(\mathrm{min})\end{array}$ & $\begin{array}{c}\text { Survival } \\
(\%)\end{array}$ & $\begin{array}{c}\text { Average } \\
\text { time of } \\
\text { Death } \\
(\mathrm{min})\end{array}$ & $\begin{array}{c}\text { Survival } \\
(\%)\end{array}$ & $\begin{array}{c}\text { Average } \\
\text { time of } \\
\text { Death } \\
(\mathrm{min})\end{array}$ \\
\hline (i) & 10 & $37 \pm 2.9$ & 10 & $40 \pm 3.8$ & 10 & $33 \pm 1.4$ & 0 & $25 \pm 0.6$ \\
(ii) & 0 & $36 \pm 1.6$ & 10 & $38 \pm 3.7$ & 10 & $31 \pm 3.5$ & 10 & $26 \pm 2.4$ \\
(iii) & 10 & $36 \pm 4.3$ & 0 & $31 \pm 4.6$ & 20 & $30 \pm 1.5$ & 10 & $27 \pm 1.4$ \\
(iv) & 10 & $35 \pm 2.3$ & 0 & $29 \pm 3.2^{* \#}$ & 10 & $33 \pm 3.7$ & 10 & $27 \pm 2.19$ \\
(v) & 10 & $31 \pm 3.7$ & 0 & $29 \pm 3.8^{* \#}$ & 0 & $35 \pm 2.4$ & 10 & $29 \pm 1.8$ \\
\hline
\end{tabular}

(i) $L Q Q$ venom alone

(ii) $L Q Q$ venom 3 min after $V$

(iii) $L Q Q$ venom 5 min before $V$

(iv) $L Q Q$ venom 15 min before $V$

${ }^{a} \mathrm{n}=10$ male mice/group; weight $=20.3 \pm 0.09 \mathrm{~g}$

* values significantly different from (i) ( $\left.{ }^{*} P<0.05\right)$

\# values significantly different from (ii) ( ${ }^{\#} \mathrm{P}<0.05$ )

- All animals injected with either $0.9 \% \mathrm{NaCl}$ or $\mathrm{V}$ (controls) were alive and well after $24 \mathrm{~h}$. 
A. R. Al-Shanawani et al. THE EFFECTS OF A SODIUM AND A CALCIUM CHANNEL BLOCKER ON LETHALITY OF MICE INJECTED WITH THE YELLOW SCORPION (Leiurus quinquestriatus) VENOM. J. Venom. Anim. Toxins incl. Trop. Dis., 2005, 11, 2, p. 187
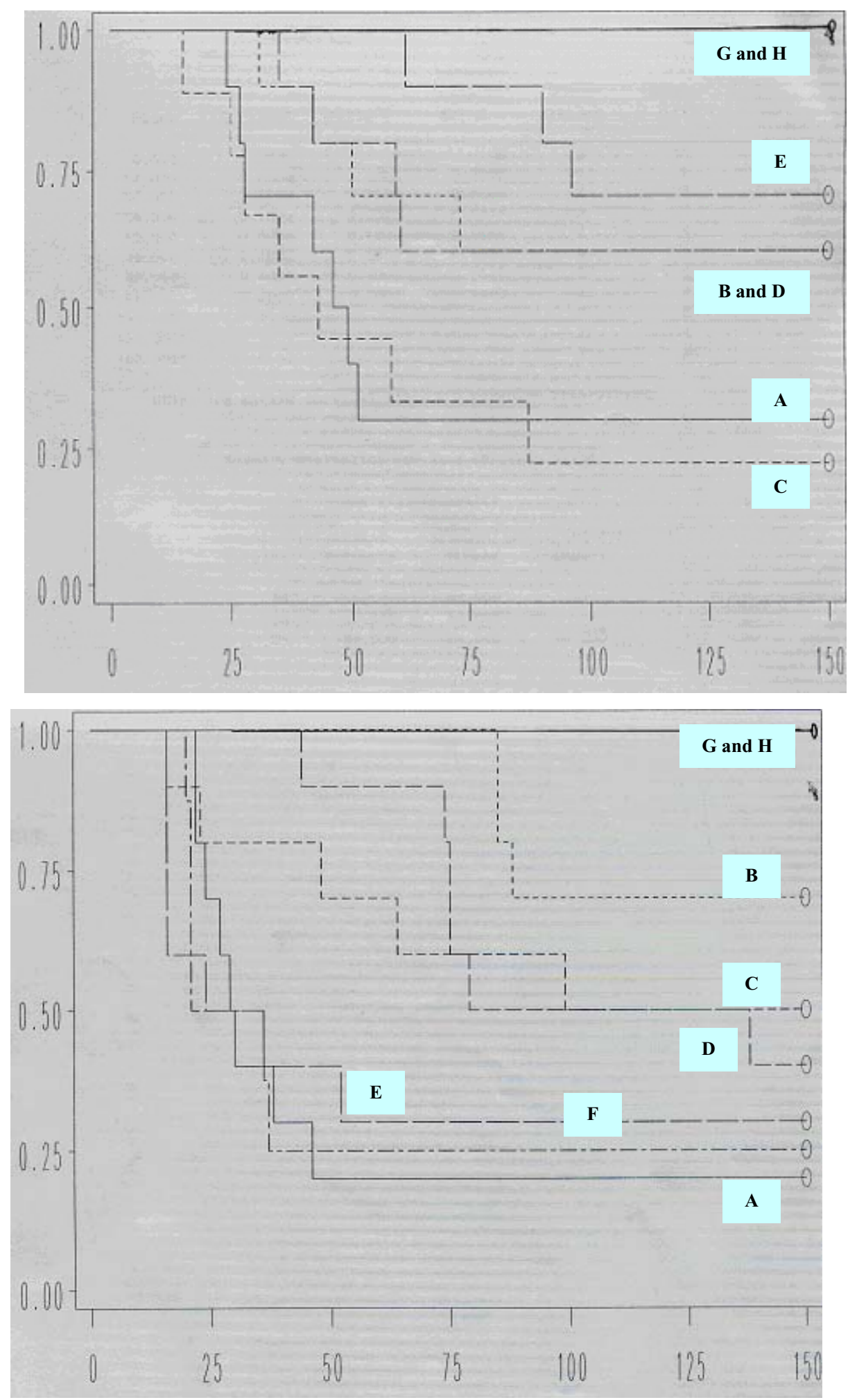

Figure 1. Survival distribution function curves of animals injected with $L Q Q$ venom $\left(250 \mu\right.$ g.kg ${ }^{-1}$, s.c.) and lidocaine at a dose of (I) $10 \mathrm{mg} \cdot \mathrm{kg}^{-1}$ or (II) $15 \mathrm{mg} \cdot \mathrm{kg}^{-1}$. The $\mathrm{Y}$-axis represents survival distribution, with (0) indicating death and (1) survival, while the $X$-axis represents survival time in minutes. (A) $L Q Q$ venom alone, (B) Lid admnistered $3 \mathrm{~min}$ before, (C) $1 \mathrm{~min}$, (D) $5 \mathrm{~min}$, (E) $15 \mathrm{~min}$, and (F) $20 \mathrm{~min}$ after $L Q Q$ venom. As control, $(\mathbf{G}) \mathrm{Lid}$ and $(\mathbf{H}) 0.9 \% \mathrm{NaCl}$ were administered alone. 
A. R. Al-Shanawani et al. THE EFFECTS OF A SODIUM AND A CALCIUM CHANNEL BLOCKER ON LETHALITY OF MICE INJECTED WITH THE YELLOW SCORPION (Leiurus quinquestriatus) VENOM. J. Venom. Anim. Toxins incl. Trop. Dis., 2005, 11, 2, p. 188
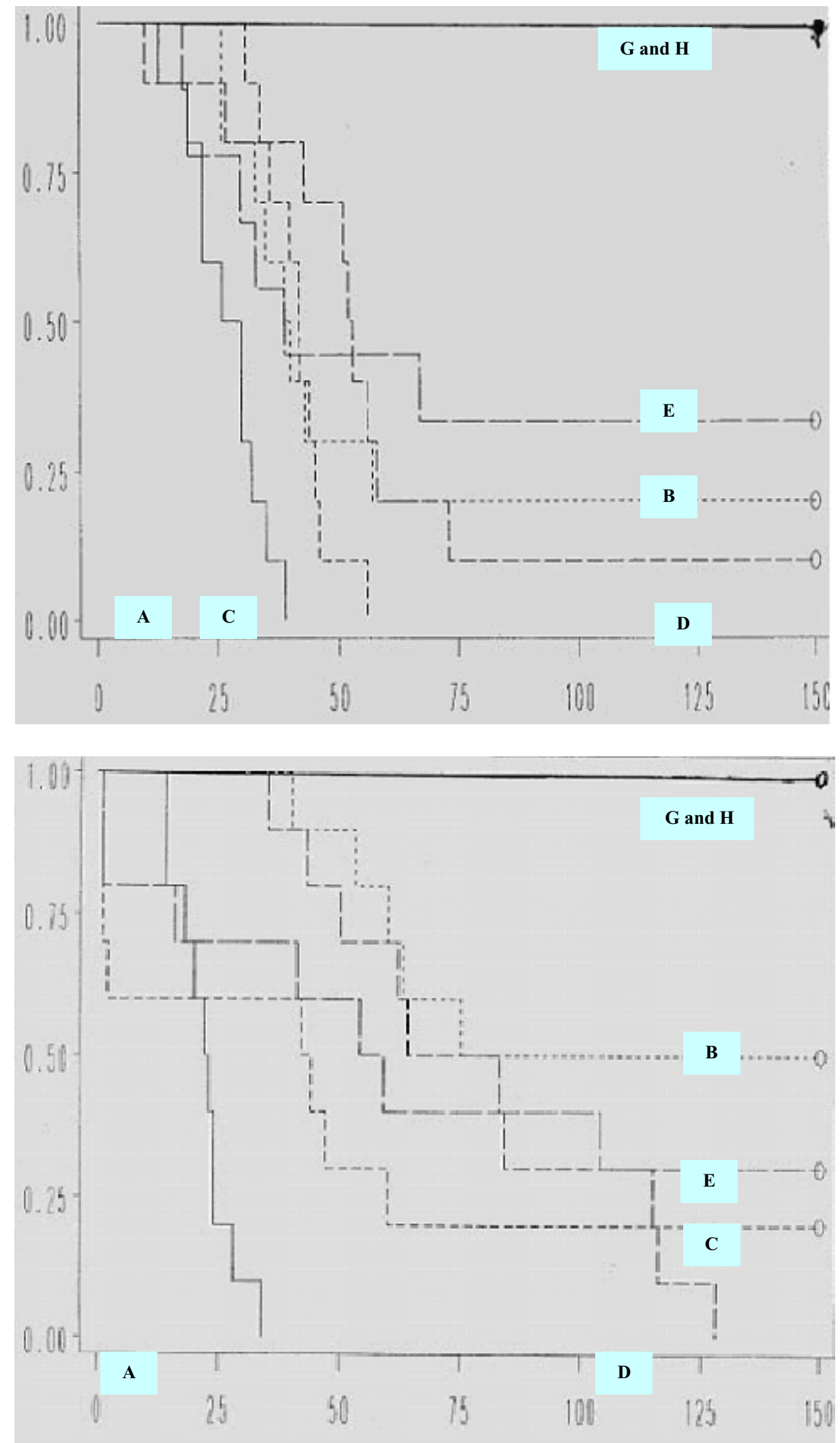

Figure 2. Survival distribution function curves of animals injected with $L Q Q$ venom (300 $\mu$ g.kg ${ }^{-1}$, s.c.) and lidocaine at a dose of either (I) $10 \mathrm{mg} \cdot \mathrm{kg}^{-1}$ or (II) $15 \mathrm{mg} \cdot \mathrm{kg}^{-1}$. The Y-axis represents survival distribution, with $(0)$ indicating death and (1) survival, while the $X$-axis represents survival time in minutes. (A) $L Q Q$ venom alone, (B) Lid administered $3 \mathrm{~min}$ before (C) $1 \mathrm{~min}$, (D) $5 \mathrm{~min}$, and (E) 15 min after $L Q Q$ venom. As control, (G) $L i d$ and $(\mathbf{H}) 0.9 \% \mathrm{NaCl}$ were administered alone. 
A. R. Al-Shanawani et al. THE EFFECTS OF A SODIUM AND A CALCIUM CHANNEL BLOCKER ON LETHALITY OF MICE INJECTED WITH THE YELLOW SCORPION (Leiurus quinquestriatus) VENOM. J. Venom. Anim. Toxins incl. Trop. Dis., 2005, 11, 2, p. 189
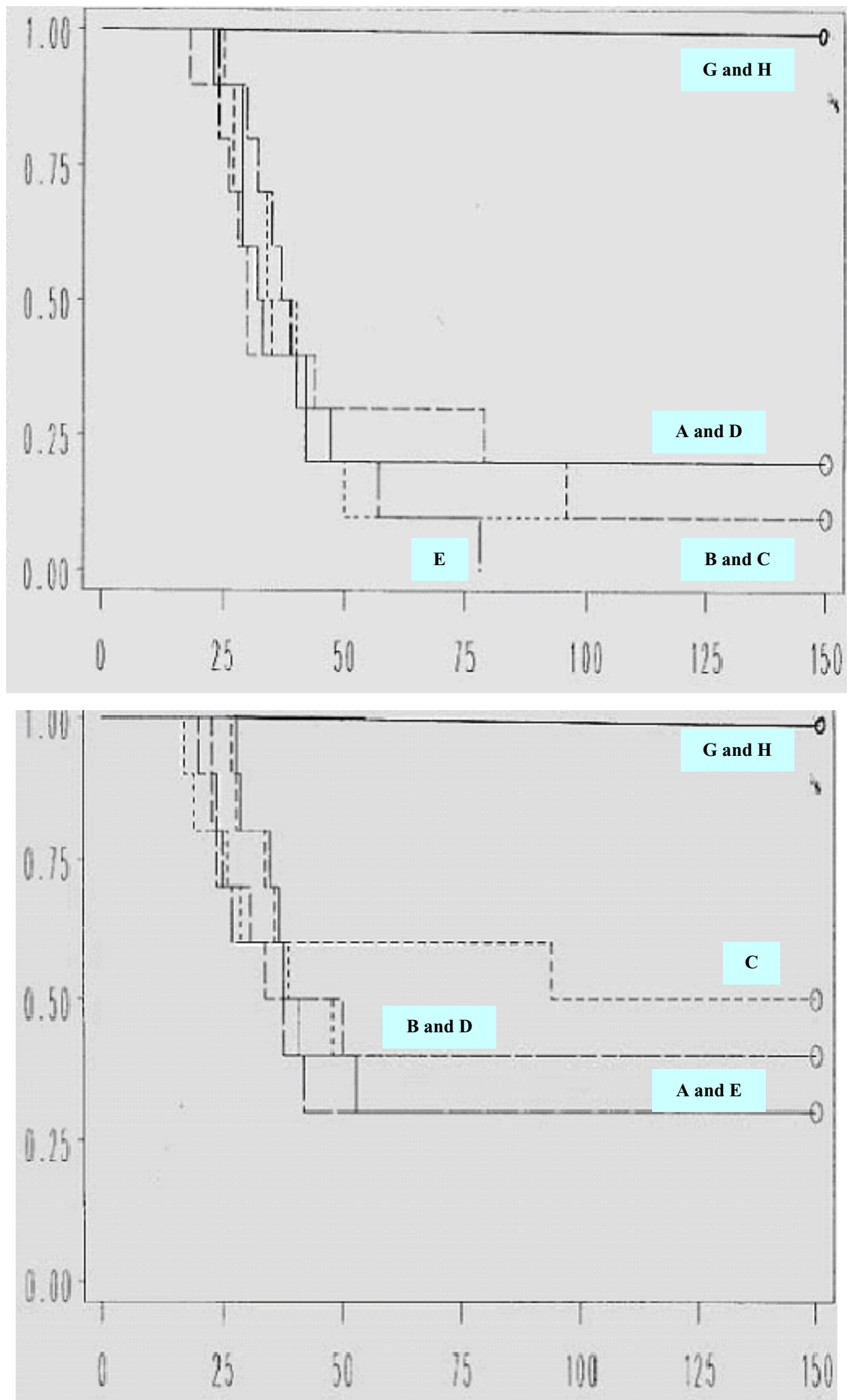

Figure 3. Survival distribution function curves of animals injected with $L Q Q$ venom $\left(250 \mu \mathrm{g} . \mathrm{kg}^{-1}\right.$, s.c.) and verapamil at a dose of either (I) $0.03 \mathrm{mg} \cdot \mathrm{kg}^{-1}$ or (II) $0.1 \mathrm{mg} \cdot \mathrm{kg}^{-1}$. The Y-axis represents survival distribution, with $(0)$ indicating death and (1) survival, while the $X$-axis represents survival time in minutes. (A) $L Q Q$ venom alone, (B) $\vee$ administered $3 \mathrm{~min}$ before, (C) $1 \mathrm{~min}$, (D) $5 \mathrm{~min}$, and (E) 15 min after $L Q Q$ venom. As control, $(\mathbf{G}) \vee$ and $(\mathbf{H}) 0.9 \% \mathrm{NaCl}$ were administered alone. 
A. R. Al-Shanawani et al. THE EFFECTS OF A SODIUM AND A CALCIUM CHANNEL BLOCKER ON LETHALITY OF MICE INJECTED WITH THE YELLOW SCORPION (Leiurus quinquestriatus) VENOM. J. Venom. Anim. Toxins incl. Trop. Dis., 2005, 11, 2, p. 190
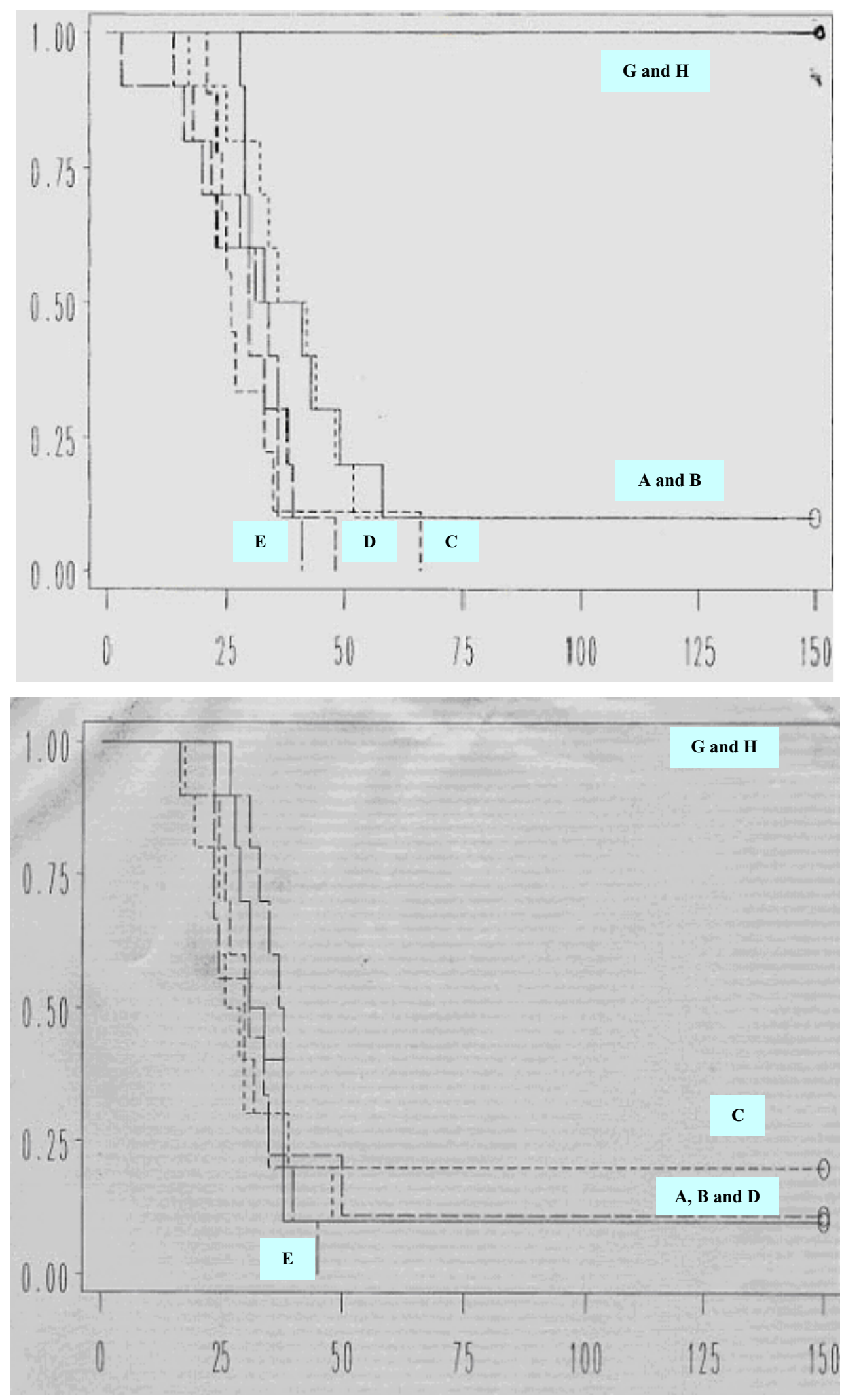

Figure 4. Survival distribution function curves of animals injected with $L Q Q$ venom $\left(300 \mu \mathrm{g}^{-\mathrm{kg}^{-1}}\right.$, s.c.) and verapamil at a dose of either (I) $0.03 \mathrm{mg} \cdot \mathrm{kg}^{-1}$ or (II) $0.1 \mathrm{mg} \cdot \mathrm{kg}^{-1}$. The Y-axis represents survival distribution, with $(0)$ indicating death and (1) survival, while the $X$-axis represents survival time in minutes. (A) $L Q Q$ venom alone, (B) $\vee$ administered 3 min before, (C) 1 min, (D) $5 \mathrm{~min}$, and (E) 15 min after $L Q Q$ venom. As control, $(\mathbf{G}) \vee$ and $(\mathbf{H}) 0.9 \% \mathrm{NaCl}$ were administered alone. 
A. R. Al-Shanawani et al. THE EFFECTS OF A SODIUM AND A CALCIUM CHANNEL BLOCKER ON LETHALITY OF MICE INJECTED WITH THE YELLOW SCORPION (Leiurus quinquestriatus) VENOM. J. Venom. Anim. Toxins incl. Trop. Dis., 2005, 11, 2, p. 191

\section{DISCUSSION}

In the present study, when $L Q Q$ venom was injected subcutaneously into mice; the percent survival ranged from $10 \%$ to $30 \%$ with $250 \mu \mathrm{g} \cdot \mathrm{kg}^{-1}$ and from $0 \%$ to $10 \%$ with $300 \mu \mathrm{g} \cdot \mathrm{kg}^{-1}$ of venom. Additionally, survival time was between 33-42 min and 22-40 min for the low and high dose of venom, respectively. It is known that despite the zoological differences between dangerous species of scorpions of the subfamily Buthinae, including $L Q Q$, most of their venoms cause similar signs and symptoms in both humans and experimental animals. These generally involve the central nervous, cardiovascular, respiratory, muscular, and gastrointestinal system, ultimately leading to death $(14,22,26)$.

In this research, lidocaine, a sodium channel blocker, generally provided protection and prolonged survival of envenomed mice when injected intravenously either before or 1, 5 and 15 min after both venom doses. These results are consistent with the hypothesis that the main targets of $L Q Q$ venom toxins are the voltage-sensitive $\mathrm{Na}^{+}$ channels, whose activation lead to sustained depolarization and exaggerated release of several transmitters and modulators $(6,25,42)$. Sodium is also an important ion for maintenance of cellular homeostasis; thus agents, such as lidocaine, that attenuate $\mathrm{Na}^{+}$intracellular increase may be a major factor in improving cell homeostasis and survival (16). It is known that lidocaine is a local anesthetic that inhibits the initiation and propagation of action potential by blocking voltage-dependent $\mathrm{Na}^{+}$channels (37). Moreover, lidocaine has been used in symptomatic treatment of scorpion envenomation, either as a local anesthetic or as an anti-arrhythmic agent $(1,13)$.

In general, lidocaine, when administered 3 min before both doses of venom, significantly increased envenomed mice survival. This is comparable with the work of Fatani et al. (12), who showed the effectiveness of pretreatment with lidocaine in prolonging survival and protecting rabbits from $L Q Q$ venom-induced pathological changes. This verifies that the lethal effects of scorpion venom seem to be due to its ability to act on $\mathrm{Na}^{+}$channels, since their blockade before venom injection prolonged survival.

In the present study, when animals were injected with Lid after envenomation by $L Q Q$, as would be expected to occur in a clinical setting, survival was prolonged, especially during earlier interventions. This would be expected since it is known that $L Q Q$ venom prolongs the inactivation of $\mathrm{Na}^{+}$channels and increases the release of several neurotransmitters and mediators (8), what usually leads in both humans and 
A. R. Al-Shanawani et al. THE EFFECTS OF A SODIUM AND A CALCIUM CHANNEL BLOCKER ON LETHALITY OF MICE INJECTED WITH THE YELLOW SCORPION (Leiurus quinquestriatus) VENOM. J. Venom. Anim. Toxins incl. Trop. Dis., 2005, 11, 2, p. 192

animals to a sustained blood pressure elevation, tachycardia, hyperpnea, increased secretions, plus signs of neuromuscular and CNS stimulation. This period is usually followed by a second phase characterized by gradually increasing hypotension, bradycardia, cardiac arrhythmias, gasping, convulsions, and ultimately cardiac plus respiratory arrest and death $(3,13,23,27,43,46)$, many of which were observed in the envenomed mice of the present work. Thus, $\mathrm{Na}^{+}$channels blockade with Lid during the early stages of the cascade of venom-evoked pathological changes would prevent further release of various mediators, and thus protect the animals from the subsequent sequelae, ultimately prolonging survival.

It was noticed that administration of a high dose of Lid $\left(20 \mathrm{mg}^{\mathrm{kg}}{ }^{-1}\right)$, especially in the later stages of envenomation (from 15 min onwards), did not provide any protection; and both survival time and percent survival were not different from the groups injected with venom alone. It is known that Lid, especially in higher doses, may cause hypotension and myocardial depression (2), which would probably aggravate the venom-evoked hypotension and bradycardia, particularly in the later stages of envenomation or with higher concentrations of venom.

Even though most of the scorpion neurotoxins act selectively on sodium channels, these venoms also contain minor components that act on other voltage-dependent channels, such as calcium (40) and potassium channels (24). Furthermore, it is also known that in addition to activation of sodium and potassium channels, $\mathrm{Ca}^{2+}$ influx is essential for neurotransmitter release in several systems (39). Thus this study attempted to verify whether a calcium channel blocker, verapamil, could provide protection against venom-elicited neurotransmitter release and its subsequent pathological sequelae. However, with the route and doses utilized, verapamil could not protect the $L Q Q$-envenomed mice, regardless of the intervention time or venom dose. On the contrary, verapamil on certain occasions significantly shortened survival time, as seen when it was injected 5 or 15 min after the high dose of venom. It is probable that verapamil doses and/or route of administration were not suitable, or that the additive effects of both, venom and verapamil, counteracted any beneficial actions. It is known that verapamil, by blocking the $\mathrm{Ca}^{2+}$ channels in the cardiovascular system, may lead to cardiac depression and hypotension $(28,39)$, effects also observed with $L Q Q$ venom especially in the later stages. Alternatively, the ineffectiveness of verapamil may be explained by the fact that it only blocks Ltype calcium channels (5) and thus lacks protective effects on other types of calcium 
A. R. Al-Shanawani et al. THE EFFECTS OF A SODIUM AND A CALCIUM CHANNEL BLOCKER ON LETHALITY OF MICE INJECTED WITH THE YELLOW SCORPION (Leiurus quinquestriatus) VENOM. J. Venom. Anim. Toxins incl. Trop. Dis., 2005, 11, 2, p. 193

channels. Furthermore Casali et al. (5) showed that venom-induced release of acetylcholine is mediated via P-type calcium channels, which are probably not affected by verapamil. Further work is needed to assess the exact role, if any, of calcium channels in scorpion envenomation.

\section{CONCLUSION}

This study supports the hypothesis that the detrimental effects of $L Q Q$ venom are mainly due to $\mathrm{Na}^{+}$channels activation and consequent pathological changes in several systems of the body, leading ultimately to death. It was evident that blockade of voltage-sensitive $\mathrm{Na}^{+}$channels with lidocaine, as early as possible, was able to halt the progressive damages caused by scorpion envenomation and prolong survival. Additional studies are underway in order to assess how lidocaine protects the animals, by undertaking a thorough investigation on its protective effects on the different systems of envenomed animals, especially the most affected ones, the cardiovascular and respiratory system.

\section{ACKNOWLEDGMENT}

Special thanks to King Abdulaziz City for Science and Technology for their generous grant; Antivenom Center at the King Fahad National Guard Hospital for collecting and milking the scorpions; and Biomedical Statistics Department at the King Faisal Specialist Hospital Research Center for their help with the statistics.

\section{REFERENCES}

1 BARZILAY Z., SHAHER E., SCHNEEWEISS A., MOTRO M., SHEM-TOV A., NEUFELD HN. Myocardial damage with life-threatening arrhythmia due to scorpion sting. Eur. Heart. J., 1982, 3, 191-3.

2 BAWASKAR HS., BAWASKAR PH. Cardiovascular manifestations of severe scorpion sting in India (review of 34 children). Ann Trop. Ped., 1991a, 11, 3817.

3 BAWASKAR HS., BAWASKAR PH. Scorpion sting: a review of 121 cases. J. Wilderness Med., 1991b, 2, 164-74.

4 BORNEMAN J., HAHIN R. Purification of protein toxins from Leiurus quinquestriatus hebraeus that modify $\mathrm{Na}^{+}$channels. Toxicon, 1993, 31, 101938. 
A. R. Al-Shanawani et al. THE EFFECTS OF A SODIUM AND A CALCIUM CHANNEL BLOCKER ON LETHALITY OF MICE INJECTED WITH THE YELLOW SCORPION (Leiurus quinquestriatus) VENOM. J. Venom. Anim. Toxins incl. Trop. Dis., 2005, 11, 2, p. 194

5 CASALI TA., GOMEZ RS., MORAES-SANTOS T., GOMEZ MV. Differential effects of calcium channel antagonists on tityustoxin and ouabain-induced release of $\left[{ }^{3} \mathrm{H}\right]$ acetylcholine from brain cortical slices. Neuropharm., 1995, 6, 599-603.

6 CATTERALL WA. Neurotoxins that can act on voltage-sensitive sodium channels in excitable membranes. Ann. Rev. Pharmac., 1980, 20, 15-43.

7 CHHATWAL GS., HABERMAN E. Neurotoxins, protease inhibitors and histamine releasers in the venom of the Indian red scorpion (Buthus tamulus): isolation and partial characterization. Toxicon, 1981, 19, 807-23.

8 COURAUD F., JOVER E., DUBOIS JM., ROCHAT H. Two types of scorpion toxin receptor sites, one related to the activation the other to the inactivation of the action potential $\mathrm{Na}^{+}$channel. Toxicon, 1982, 20, 9-16.

9 COURAUD F., ROCHAT H., LISSITZKY S. Binding of scorpion neurotoxins to chick embryonic heart cells in culture and relationship to calcium uptake and membrane potential. Biochem., 1980, 19, 457-62.

10 DITTRICH K., POWER AP., SMITH NA. Scorpion sting syndrome, a ten year experience. Ann. Saudi. Med., 1995, 15, 148-55.

11 EL-HAYEK R., LOKUTA A., AREVAlO C., VALDIVIA H. Peptide probe of ryanodine receptor function. J. Biol.. Chem., 1995, 270, 28696-704.

12 FATANI AJ., HARVEY AL., FURMAN BL., ROWAN EG. The effects of lignocaine on actions of the venom from the yellow scorpion "Leiurus quinquestriatus" in vivo and in vitro. Toxicon, 2000, 38, 1787-1801.

13 FREIRE-MAIA L., CAMPOS JA. Response to the letter to the editor by Gueron and Ovsyshcher on the treatment of the cardiovascular manifestations of scorpion envenomation. Toxicon, 1987, 25, 125-30.

14 FREIRE-MAIA L., CAMPOS JA. Pathophysiology and treatment of scorpion poisoning. In: WORLD CONGRESS ON ANIMAL, PLANT AND MICROBIAL TOXINS, 9, Stillwater, 1989. Proceedings... Oxford: Pergamon Press, 1989. p.139-59.

15 FREIRE-MAIA L., DE MATOS IM. Heparin or a PAF antagonist (BN-52021) prevents the acute pulmonary edema induced by Tityus serrulatus scorpion venom in the rat. Toxicon, 1993, 31, 1207-10.

16 FRIED E., AMORIM P., CHAMBERS G., COTTRELL JE., KASS IS. The importance of sodium for anoxic transmission damage in rat hippocampal slices: mechanism of protection by lidocaine. J. Physiol., 1995, 4892, 537-65. 
A. R. Al-Shanawani et al. THE EFFECTS OF A SODIUM AND A CALCIUM CHANNEL BLOCKER ON LETHALITY OF MICE INJECTED WITH THE YELLOW SCORPION (Leiurus quinquestriatus) VENOM. J. Venom. Anim. Toxins incl. Trop. Dis., 2005, 11, 2, p. 195

17 FULGA I., STROESCU V. Experimental research on the effect of calcium channel blockers nifedipine and verapamil on the anxiety in mice. Rom. J. Physiol., 1997, 34, 127- 36.

18 GOMEZ MV., FAR ELL N. The effect of tityustoxin and ruthenium red on the release of acetylcholine from slices of cortex of rat brain. Neuropharmac., 1985, 24, $1103-7$.

19 GORDON D., GUREVITZ M. The selectivity of scorpion $\alpha$-toxins for sodium channel subtypes is determined by subtle variations at the interacting surface. Toxicon, 2003, 41, 125-8.

20 GRUPP L., GRUPP G., GUERON M., ADOLPH R., FOWLER O. Effect of the venom of the yellow scorpion (Leiurus quinquestriatus) on the isolated workperforming guinea pig heart. Toxicon, 1980, 18, 261-70.

21 GUERON M., MARGULIS G., SOFER S. Echocardiographic and radionuclide angiographic observations following scorpion envenomation by Leiurus quinquestriatus. Toxicon, 1990, 28, 1005-9.

22 GUERON M., OVSYSHCHER I. Cardiovascular effects of scorpion venoms. In: TU AT. Ed. Handbook of natural toxins, insect poisons, allergens and other invertebrate venoms. New York: Marcel Dekker, 1984: 639-57.

23 GUERON MD., ILIA MD., SOFER MD. The cardiovascular system after scorpion envenomation, a review. Clin. Toxicol. J., 1992, 30, 245-58.

24 HARVEY A., ROMAN E., VETANPOUR H., FATEHI M., CASTANEDA O., KARLSSON E. Potassium channel toxins and transmitter release. Ann. N. Y. Acad. Sci., 1994, 710, 1-10.

25 HARVEY AL., ANDERSON AJ., BRAGA MM., MARSHALL DL., ROWAN EG., VATANPOUR H., CASTANEDA O., KARLSSON E. Toxins affecting neuronal ions channels. In: GOPALAKRISHNAKONE P., TAN CK. Eds. Recent Advances in Toxicology Research. Singapore: National University of Singapore, 1992: 59-70.

26 ISMAIL M. The scorpion envenoming syndrome. Toxicon, 1995, 33, 825-58.

27 ISMAIL M., OSMAN OH., IBRAHIM SA., EL-ASMAR MF. Cardiovascular and respiratory responses to the venom from the scorpion Leiurus quinquestriatus. E. Afr. Med. J., 1972, 49, 273-81. 
A. R. Al-Shanawani et al. THE EFFECTS OF A SODIUM AND A CALCIUM CHANNEL BLOCKER ON LETHALITY OF MICE INJECTED WITH THE YELLOW SCORPION (Leiurus quinquestriatus) VENOM. J. Venom. Anim. Toxins incl. Trop. Dis., 2005, 11, 2, p. 196

28 IWASAKI H., OHMORI H., OMOTE K., KAWAMATA M., SUMITA S., YAMAUCHI M., NAMIKI A. Potentiation of local lignocaine-induced sensory block by calcium channel blockers in rats. Br. J. Anaesth., 1996, 77, 243-7.

29 JACOBS TP., JOHNSON DG., WILLIAMS RH. Epinephrine secretion from the perfused adrenal gland produced by scorpion toxin. Toxicol. Appl. Pharmac., 1978, 46, 405-9.

30 KAPUR PA., GROGAN DL., FOURNIER DJ. Cardiovascular interactions of lidocaine with verapamil or diltiazem in the dog. Anesthesiol., 1988, 68, 79-85.

31 LAHIRI SC., CHAUDHURI AN. Release of kinin by the scorpion (Heterometrus bengalensis, C. L. Köch) venom. Ind. J. Exp. Biol., 1983, 21, 198-202.

32 LANGER SZ., ADLER-GRASCHINSKY E., ALMEIDA AP., DINIZ CR. Prejunctional effects of a purified toxin from the scorpion Tityus serrulatus: release of ${ }^{3} \mathrm{H}$-noradrenaline and enhancement of transmitter overflow elicited by nerve stimulation. Naunyn-Schmiedeberg's Arch. Pharmac., 1975, 287, 243-59.

33 MEKKI AM., MOHEY EL-DEAN MZ. Serum interleukin-1 $\beta$, interleukin-6, nitric oxide and a1-antitrypsin in scorpion envenomed children. Toxicon, 1998, 36, 1851-9.

34 MILLER LC., TAINTER ML. Estimation of $\mathrm{ED}_{50}$ and its error. Proc. Soc. Exp. Biol. Med., 1949, 57, 261-4.

35 MILLER RJ. Multiple calcium channels and neuronal function. Science, 1987, 235, 46-52.

36 POSSANI LD., BECERRIL B., DELEPIERRE M., TYTGAT J. Scorpion toxins specific for $\mathrm{Na}^{+}$-channels. Eur. J. Biochem., 1999, 264, 287-300.

37 STRICHARTZ GR., RITCHIE JM. The action of local anesthetics on ion channels of excitable tissues. In: STRICHARTZ GR. Ed. Local Anesthetics, Handbook of Experimental Pharmacology. Berlin: Springer-Verlag, 1987: 21-53.

38 UCHITEL OD. Toxins affecting calcium vhannels in neurons. Toxicon, 1997, 35, 1161-91.

39 VALDIVIA H., FUENTES O., EL-HAYEK R., MORRISSETTE J., CORONADO R. Activation of the ryanodine receptor $\mathrm{Ca}^{2+}$ release channel of sarcoplasmic reticulum by a novel scorpion venom. J. Biol. Chem., 1991, 266, 19135-8.

40 VALDIVIA HH., KIBBY MS., LEDERER WJ., CORONADO R. Scorpion toxins targeted against the sarcoplasmic reticulum $\mathrm{Ca}^{2+}$ - release channel of skeletal and cardiac muscle. Physiol., 1992, 89, 12185-9. 
A. R. Al-Shanawani et al. THE EFFECTS OF A SODIUM AND A CALCIUM CHANNEL BLOCKER ON LETHALITY OF MICE INJECTED WITH THE YELLOW SCORPION (Leiurus quinquestriatus) VENOM. J. Venom. Anim. Toxins incl. Trop. Dis., 2005, 11, 2, p. 197

41 VITAL BO., FONTANA MD., EROSANTJNIO DA., HELUANY NF., LEITE GB. Actions of Androctonus australis and Leiurus quinquestriatus venoms in the rat isolated atria and anesthetized rats; effect of magnesium and lidocaine. J. Nat. Toxins., 2002, 11, 1-13.

42 WANG GK., STRITCHARTZ GR. Purification and physiological characterization of neurotoxins from venoms of scorpion Centruroides sculpturatus and Leiurus quinquestriatus. Molec. Pharmac., 1983, 23, 519-33.

43 WATT DD., SIMARD JM. Neurotoxic proteins in scorpion venom. J. Toxicol. Toxin Rev., 1984, 3, 181-221.

44 WHEELER KP., WATT DD., LAZDUNSKI M. Classification of $\mathrm{Na}^{+}$channel receptors specific for various scorpion toxins, Pflügers Archiv. Eur. J. Physiol., 1983, 397, 164-5.

45 YAROM R., BRAUN K. Reversible myocardial damage by scorpion venom in perfused rat heart. Toxicon, 1974, 12, 347-51.

46 ZLOTKIN E., MIRANDA F., ROCHAT H. Chemistry and pharmacology of Buthinae scorpion venoms. In: BETTINI S. Ed. Handbook of Experimental Pharmacology, Arthropod Venoms. Berlin: Springer-Verlag, 1978: 317-69. 